\title{
What does the performance of the Dow Jones Sustainability Group Index tell us?
}

\author{
Pontus Cerin \\ pontus.cerin@lector.kth.se \\ Peter Dobers \\ peter.dobers@lector.kth.se \\ Department of: \\ Industrial Economics and Management \\ Royal Institute of Technology \\ Stockholm, Sweden \\ INDEK-KTH \\ SE-100 44 Stockholm \\ Sweden
}




\section{Abstract}

The Dow Jones Sustainability Group Index (DJSGI) is really a family of indexes used to identify and track the performance of sustainably-run companies. When the DJSGI was introduced in September 1999, it was claimed to outperform the more generalised Dow Jones Global Index (DJGI) in respect to market capitalisation growth. Corporations, NGOs and governmental agencies often refer to the DJSGI for illustrating that integrating economic, environmental and social factors into the operations and management of a company increases shareholder value and business activity transparency. The DJSGI is also used by global corporations to legitimise the efforts they put into sustainability. However, there are no studies carried out to date that illuminate the business activity transparency of the DJSGI. This study investigates the structure and transparency of the DJSGI compared with the DJGI. The results of this study show that the DJSGI focuses more on the technology sector than the general DJGI does. The average market capitalisation value of companies listed in the DJSGI was found to be two-and-a-half times the corresponding average for those listed in the DJGI. This raises some legitimate questions. Does the superior performance of the DJSGI reflect the greater efforts DJSGI companies put into sustainability, or a dependence on asymmetric distributions in company sectors, world regions or market capitalisation? This paper therefore endeavours to illustrate the transparency of the DJSGI.

\section{Keywords}

Dow Jones Sustainability Group Index, sustainable corporations, green business, shareholder value, technology, market capitalisation value. 


\section{Content}

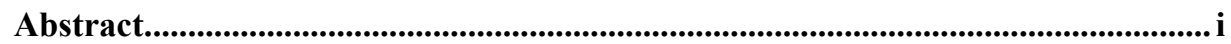

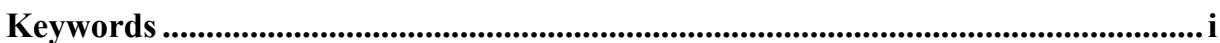

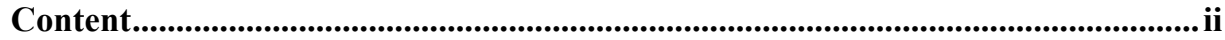

1. Assessing environmental performance.............................................................. 1

2. The Dow Jones Sustainability Group Index ........................................................ 3

3. The Dow Jones Sustainability Group Index as a benchmarking tool ................. 5

4. Methodology ....................................................................................................... 7

5. Sector distribution comparisons .............................................................. 8

6. Regional distribution comparisons.............................................................................. 10

7. Average market capitalisation comparisons........................................................... 12

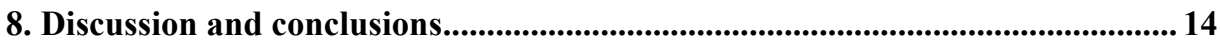

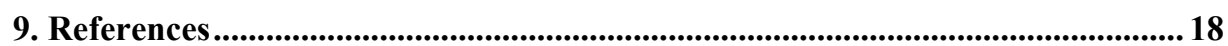

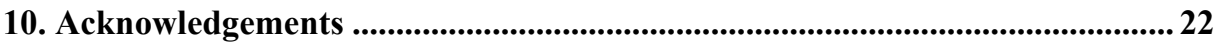




\section{Assessing environmental performance}

Several attempts have recently been made to assess the environmental performance of corporations. These can be categorised into three approaches: (1) holding general discussions about environmental reports (Kolk and van de Wateringen, 2001; Niskanen and Nieminen, 2001; Wheeler and Elkington, 2001), (2) addressing how environmental reports can be used to guide corporations in their learning about their environmental performance (Herremans et al, 1999), and (3) formulating environmental reports to optimise their reliability, consistency and relevance (Kolk, 1999; Ljungdahl, 1999). It has been shown that setting environmental goals (Ransom et al, 1999) and conducting environmental audits (Diamantis, 1999) prior to the formulation of environmental indicators can illuminate relevant processes, and experience from the US shows that when institutionalised effectively, environmental performance indicators have proven to be quite successful (Stead et al, 1998). What the three environment-assessment processes mentioned above have in common is that they provide sustainability-focussed corporations with a means to measure their environmental performance, while at the same time increasing its visibility and transparency (Ball et al, 2000; Bowen, 2000). These methods attempt to reflect company sustainability from the inside out. Change can also be triggered by specific internal processes within a corporation that radiate outward. These changes can be referred to as inside-out changes, and can be triggered for example, by a corporation's focused efforts to achieve recognised standards of accreditation such as ISO 14001 or the British Standard, BS 7750 (Robinson and Clegg, 1998).

An inside-out approach to achieving sustainability is by definition initiated by the corporation and does not necessarily include an evaluation of the corporation itself. On the other hand, an outside-in approach is based on an independent evaluation and comparison of various corporations and their activities, their influences on a particular industrial sector, company size, and even the type of internal environmental regulation (Baylis et al, 1998; Dobers, 1999). The recently launched Dow Jones Sustainable Group Index (DJSGI) attempts to 
achieve sustainable business processes from the outside in. It is claimed that the DJSGI, which includes corporations that exhibit good, active sustainability track records in the areas of social, environmental and economic performance, has actually shown better development than the Dow Jones Global Index (DJGI) (Dow Jones, 1999a). It has been suggested recently that the DJSGI will improve global transparency and benchmarking, thereby improving current methodologies for screening processes aimed towards achieving sustainability (Dobers and Wolff, 2000) but they also state that:

"The point is not that the Dow Jones methodology is perfect or correct...(but) that one of the global players in the financial market gives legitimacy to issues that were previously treated as "soft". The new index will contribute to forcing companies to make transparent, report and evaluate continuously, as well as communicate their measures in the sustainable framework." (Dobers and Wolff, 2000:147)

This paper discusses the DJSGI in detail, analysing its structure focusing on market capitalisation, regional and sector distributions compared with other Dow Jones indexes. This paper attempts to increase the transparency of the DJSGI itself in the wake of claims that it enhances the transparency of sustainability processes within international corporations. Though the criteria used for sustainability within the DJSGI are themselves important, they have not been examined here. After first presenting DJSGI objectives, concepts, key attributes, assessment criteria and evaluation systems, the paper then focuses on sector distribution, regional distribution and market capitalisation of the DJSGI, comparing these with corresponding DJGI distributions. 


\section{The Dow Jones Sustainability Group Index}

"I welcome the efforts of Sustainable Business Investor in Europe to engage investors in delivering sustainable development.

Businesses will face many challenges and opportunities as we try to deliver a sustainable Europe. We have already seen firms that are acting in a sustainable manner enjoy a distinct advantage over their competitors, and we can expect this advantage to increase in size and frequency. Investors have an important role to play in monitoring and encouraging sustainability in businesses - both for their own and for society's sake." Margot Wallstrom, EU Environment Commissioner on the homepage of Sustainable Business Investors Europe in association with Dow Jones Sustainability Group Indexes and SAM Sustainability Group (http://www.sbi-e.com/ retrieved on 13 February 2001).

In September 1999, the Dow Jones Sustainability Group Indexes GmbH (a partnership between Dow Jones Global Indexes and the Swiss-based SAM Sustainability Group) launched the first global indexes for tracking the performance of sustainability-driven corporations worldwide, the DJSGI. As corporate sustainability has long been assumed to increase long-term value for shareholders, the DJSGI is seen as creating a "hard" benchmark for corporations genuinely interested in sustainability issues, rather than just superficially canvassing the "soft" issues associated with sustainable development (Dobers and Wolff, 2000:147f; WCED, 1987). Though the DJSGI is committed to addressing the economic, environmental and social elements underpinning sustainability, the superior performance of pro-active, costeffective and responsible corporations is directly related to their commitment to the following five corporate sustainability principles (Dow Jones, 1999a):

1. Innovative technology - in products and services

2. Corporate governance - including management, organisational capability, corporate 
culture and stakeholder relations

3. Shareholder relations - based on sound financial returns and long-term economic growth

4. Industrial leadership - by demonstrating commitment

5. Social well-being

These principles facilitate the quantification of sustainability performance in corporations (especially in the financial sector) aiming to pursue sustainability opportunities and avoid sustainability risks.

The DJSGI is really a family of 20 different indexes derived from the DJGI. Five of these indexes are geographical in character: the world as a whole, Europe, North America, the Asia-Pacific region, and the USA. Each geographical index is then crossed with subset indexes that exclude stock associated with corporations involved in tobacco, gambling or alcohol. Some 226 of the largest 2899 corporations in the DJGI have been included in the DJSGI. Selection is based on analysis and evaluation of information returned via questionnaire from top-level management, contained in company policies and reports, and continuous review of stakeholder relations as seen through the relevant media. The top-ranked $10 \%$ of performers in each industry group are included in the DJSGI and subject to annual review. The sustainability performance of corporations included in the DJSGI in 1998 has been "backcasted" to 1993 to chart their historical performance.

The DJGI on the other hand (against which the DJSGI has been benchmarked) seeks to cover $80 \%$ of the market capitalisation on the major stock exchanges throughout the world (this figure increased to $95 \%$ in mid 2000). Various exclusion factors play a role here, for instance where non-residents are prohibited from controlling more then $25 \%$ of company stock, then only $25 \%$ of this market capitalisation is included in the DJGI. The DJGI with its 2899 companies is divided into various regional indexes, which are in turn crossed by 122 industrial sectors. 


\section{The Dow Jones Sustainability Group Index as a benchmarking tool}

The DJSGI is designed to provide a worldwide benchmarking tool for new products and services introduced by financial institutions. Institutions interested in using the DJSGI to compare the performance of their own financial instruments are required to pay a fee. Since the launch of the DJSGI in September 1999, 25 licences have been issued to financial institutions in 11 countries. These licensees have created a variety of index-based financial products including active and passive funds, equity baskets and warrants (see Table 1).

Table 1. DJSGI licensees by country, February 15, 2001 (http://www.sustainability-index.com)

$\begin{array}{lll}\text { Licensee } & \text { Country } & \text { Type } \\ \text { Baloise Insurance } & \text { Switzerland } & \text { Fund } \\ \text { Banque Générale de Luxembourg } & \begin{array}{l}\text { Luxembourg } \\ \text { Bear Stearns }\end{array} & \text { Fund } \\ \text { guaranteed note } & \text { UK } & \text { Capital } \\ \text { Cordius Asset Management } & \text { Belgium } & \text { Fund } \\ \text { Credit Suisse Asset Management } & \text { Switzerland } & \text { Fund } \\ \text { DWS } & \text { Germany } & \text { Fund } \\ \text { Folksam Sak } & \text { Sweden } & \text { Fund } \\ \text { Fürst Fugger Privatbank } & \text { Germany } & \text { Fund } \\ \text { Gerling Investment KAG } & \text { Germany } & \text { Fund } \\ \text { GZ Bank } & \text { Germany } & \text { Equity } \\ \text { HypoVereinsbank } & \text { Germany } & \text { Warrant } \\ \text { ING Fund Management B.V. } & \text { Netherlands } & \text { Fund } \\ \text { Invesco } & \text { Germany } & \text { Fund } \\ \text { Kepler Fonds KAG } & \text { Austria } & \text { Fund } \\ \text { Nikko Asset Management } & \text { Japan } & \text { Fund } \\ \text { Oppenheim KAG } & \text { Germany } & \text { Fund } \\ \text { Robeco Groep } & \text { Netherlands } & \text { Fund } \\ \text { Rothschild \& Cie Gestion } & \text { France } & \text { Fund } \\ \text { Skandinaviska Enskilda Bank } & \text { Sweden } & \text { Fund } \\ \text { SPP } & \text { Sweden } & \text { Fund } \\ \text { State Street Global Advisors } & \text { Germany } & \text { Fund } \\ \text { Sustainable Asset Management (SAM) Switzerland } & \text { Fund } \\ \text { Sustainable Performance Group } & \text { Switzerland } & \text { Investment } \\ \text { Westpac Investment Managements } & \text { Australia } & \text { Index fund }\end{array}$


Four market-driven DJSGI attributes have been highlighted as accounting for its suitability as a benchmarking tool (Dow Jones, 1999a):

1. Global representation - of sustainability-driven companies from the global DJGI

2. Rational assessment method - a multi-factor analysis including equal weighting of environmental, social and economical criteria

3. Consistent method - including an industry specific questionnaire, the analysis of company policies and reports as well as stakeholder relations

4. Flexibility - inclusion of certain regions and exclusion of others.

While the aim of the DJSGI is to function as a tool for benchmarking historical performance, it is important to note that choosing corporations for inclusion in the DJSGI was based on sustainability analysis and ranking carried out in late 1998 and early 1999. In order to achieve a benchmark for comparing historical performance, the performance of the DJSGI corporations were backcasted to December $31^{\text {st }} 1993$. This method was chosen pragmatically to overcome the near impossible task of recreating the selection process of sustainability analysis and rankings used in the past. All indexes are expressed in monthly price returns in US dollars. Table 2 shows how DJSGI stocks have performed better than DJGI stocks in all regions except Europe during this period.

Table 2. Comparison between the historical performance of the DJSGI and other benchmarking indexes, 3/95 - 3/00 (Dow Jones, 2000d).

\begin{tabular}{|l|c|c|c|c|c|}
\hline $\begin{array}{l}\text { Index I } \\
\text { Region }\end{array}$ & $\begin{array}{c}\text { World } \\
(\%)\end{array}$ & $\begin{array}{c}\text { Europe } \\
(\%)\end{array}$ & $\begin{array}{c}\text { Americas } \\
(\%)\end{array}$ & $\begin{array}{c}\text { Pacific } \\
(\%)\end{array}$ & $\begin{array}{c}\left({ }^{*}\right) \text { USA } \\
(\%)\end{array}$ \\
\hline DJSGI & 164,46 & 128,22 & 312,19 & 60,86 & 297,78 \\
\hline DJGI & 138,76 & 148,71 & 221,50 & 7,36 & $\left({ }^{* *}\right) 236,18$ \\
\hline
\end{tabular}

$\left({ }^{*}\right)$ Included in Americas

$\left({ }^{* *}\right)$ Benchmark in this case is: S\&P 500 


\section{Methodology}

In order to find out whether any non-sustainability-related factors have contributed to the higher growth seen in the DJSGI (compared with the DJGI), a formula has been constructed here to enable differences in the distribution between the index families to be studied by sector, region and market capitalisation value (see Formula 1). The DJSGI-DJGI-distribution differences are then related to the performance of the DJGI for each of the three groups. These three sets of outcomes are then individually compared to the DJSGIDJGI-performance difference. The performance values cover the full period 1995-1999 and the distributions, the turn of year 1999-2000.

Formula 1. Comparing the performance of distribution groups to the benchmarked performance difference.

$$
\begin{aligned}
& \mathrm{P}_{\text {Total -Distrib. Group }}=\mathrm{P}_{\text {Total }}-\mathrm{P}_{\text {Distrib. Group }}= \\
&\left(\mathrm{P}^{\text {DJSGI }}-\mathrm{P}^{\text {DJGI }}\right)_{\text {Total }}-\left(\sum_{\mathrm{i}=1}^{\mathrm{n}}\left(\left(\mathrm{D}_{\mathrm{i}}^{\text {DJSGI }}-\mathrm{D}_{\mathrm{i}}^{\text {DJGI }}\right) \times \mathrm{P}_{\mathrm{i}}^{\text {DJGI }}\right)\right)_{\text {Distrib. Group }} \\
& \mathrm{P}=\text { performance as of } \mathrm{Q} 1: 1995-\mathrm{Q} 4: 1999 \\
& \mathrm{D}=\text { distribution as of } \mathrm{Q} 1: 2000 \\
& \mathrm{n}=\text { number of distribution elements in distribution group } \\
& \mathrm{i}=\text { iterations of elements }
\end{aligned}
$$




\section{Sector distribution comparisons}

In February 2000 a new global industry-classification structure was applied to the business sectors in the DJSGI. This accounts for the changes to the DJSGI sector divisions that appeared after 2000. This paper focuses on the DJSGI sector distribution reported on up until January 2000. The pre-2000 structure is therefore used for estimating asymmetric sector distribution impact and the post-1999 data converted accordingly. This facilitates valid comparison of the new and the old sector distributions. Companies included in the pre-2000 DJSGI contribution are divided into nine economic sectors, which in turn are sub-divided into 73 industry groups. The DJGI companies are also divided into the corresponding nine economic sectors, but sub-divided into 122 industry groups and subgroups.

The study has found that technology and energy have been over-weighted in the DJSGI's nine economic sectors. The Technology distribution was 4.7 per cent points, and Energy 3.1 per cent points higher in the DJSGI than the DJGI. DJGI performance in these sectors shows total 5-year growth of 863 and $188 \%$ respectively. The DJGI has on the other hand a larger distribution of Financials (2.3 per cent points) and Industrials (5 per cent points) than the DJSGI, with a DJGI performance for total 5-year growth of 126 and 95\% respectively. Multiplying these sector distribution differences with the actual DJGI performance illustrates the difference in growth for an index with DJSGI sector distribution and DJGI sector performance to be compared to the DJGI itself. Table 3 illustrates an asymmetric sector distribution between the DJSGI and the DJGI, with the DJSGI exhibiting a 35 per cent unit higher performance than the DJGI. This finding agrees with Swedish-based, international technology funds that show large growth rates during the 1990s, far outperforming general funds (Dagens Industri/Fondstar, 2000www). 
Table 3. Sector distribution comparisons between DJSGI and DJGI performances applied to the DJSGI sector distribution (DJGI performances serve as the reference base)

\begin{tabular}{|c|c|c|c|c|c|}
\hline \multirow{2}{*}{$\begin{array}{l}\text { Market sector } \\
\text { distribution }\end{array}$} & C1 & $\mathrm{C2}$ & C3 & C4 & C5 \\
\hline & $\begin{array}{c}\text { DJSGI } \\
\text { Q1: } 2000 \\
(\%)\end{array}$ & $\begin{array}{c}\text { DJGI } \\
\text { Q1: } 2000 \\
(\%)\end{array}$ & $\begin{array}{c}\text { DJSGI-DJGI } \\
\text { distribution } \\
\text { difference } \\
(\%) \\
\end{array}$ & $\begin{array}{c}\text { DJGI } \\
\text { performanc } \\
\text { e Q1: 1995- } \\
\text { Q4: 1999 } \\
(\%)\end{array}$ & $\begin{array}{c}\mathrm{C}{ }^{*} \mathrm{C} 4 \\
(\%) \\
\end{array}$ \\
\hline Basic Materials & 4.4 & 3.2 & 1.2 & 15 & 0.18 \\
\hline Cyclicals & 13.9 & 13.7 & 0.2 & 42 & 0.84 \\
\hline $\begin{array}{l}\text { Non-cyclicals } \\
\text { (incl. health care) }\end{array}$ & 13.8 & 13.8 & 0 & 158 & 0 \\
\hline Energy & 8.0 & 4.9 & 3.1 & 188 & 5.83 \\
\hline Financials & 14.6 & 16.9 & -2.3 & 126 & -2.90 \\
\hline Industrials & 6.3 & 11.3 & -5.0 & 95 & -4.75 \\
\hline $\begin{array}{l}\text { Technology } \\
\text { (incl. datacom \& biotech) }\end{array}$ & 25.5 & 20.8 & 4.7 & 863 & 40.56 \\
\hline $\begin{array}{l}\text { Utilities } \\
\text { (incl. telecom providers) }\end{array}$ & 13.4 & 15.2 & -1.8 & 259 & -4.66 \\
\hline Independent/Others & - & - & - & - & - \\
\hline Total & 99.9 & 99.8 & 0.1 & 24.47 & $\left({ }^{*}\right) 35.10$ \\
\hline
\end{tabular}

$\left({ }^{*}\right)$ The reported DJSGI-DJGI performance difference is however 50.03 per cent points. Information retrieved from: Dow Jones (2000c; 2000d; 1999c) available at indexes.dowjones.com/djsgi/ and Dow Jones (2000a; 2000b; 1999b) available at indexes.dowjones.com/djgi/ as well as the five-year performance data retrieved from DJGI Data Server.

Multiplying the DJSGI-DJGI sector distribution differences by DJGI sector performances reveals that a large portion of the better DJSGI performance may originate from the relatively higher market distribution toward sectors with higher growth. The largest difference in sector distribution between the DJSGI and the DJGI is found in the very-high performing technology sector, which is in surplus in the DJSGI. 


\section{Regional distribution comparisons}

The DJSGI is divided into regions following the structure of the benchmark index, DJGI. This section of the paper examines the top-ranking regional distribution of the two indexes by market-capitalisation size, and where differences exist, exploring how those may affect the index performances. Comparing the performances of the regional indexes over the second half of the 1990s provides an indication of how these distribution differences might affect the outcome of the DJSGI (see Table 4).

Table 4. Regional distribution comparisons between DJSGI and DJGI.

\begin{tabular}{|l|c|c|c|}
\hline Regional distribution & $\begin{array}{c}\text { DJSGI World } \\
(\%)\end{array}$ & $\begin{array}{c}\text { DJGI World } \\
(\%)\end{array}$ & $\begin{array}{c}\text { Difference } \\
\text { (per cent points of total) }\end{array}$ \\
\hline Americas (excl USA) & 5.67 & 3.26 & 2.41 \\
\hline USA & 37.81 & 49.50 & -11.69 \\
\hline Europe (excl. S. Africa) & 43.28 & 29.49 & -4.70 \\
\hline Pacific & 13.04 & 17.74 & \\
\hline World (excl. S. Africa) & $\mathbf{9 9 . 8 0}$ & $\mathbf{9 9 . 9 9}$ & \\
\hline
\end{tabular}

The regional weightings are retrieved from: Dow Jones (2000d), available at

indexes.dowjones.com/djsgi/ and DJGI regional components weightings as of July 4, 2000 at indexes.dowjones.com/djgi/.

In order to illustrate how the regional distribution differences may be affecting the performance of the DJSGI, the DJSGI-DJGI regional asymmetries are multiplied by the regional DJGI performances (see Table 5).

Despite the predomination of European corporations in the DJSGI, as of $31^{\text {st }}$ March 2000 market capitalisation is fairly evenly divided between the two major regions, Europe and the USA. This is due to the fact that the US corporations achieve a market capitalisation of more than double their counterparts in Europe (see Table 6). 
Table 5. Comparison of DJSGI and DJGI performances by regional distribution applied to the DJSGI regional distribution (DJGI performances serve as the reference base)

\begin{tabular}{|l|c|c|c|}
\hline Regional distribution & $\begin{array}{c}\text { DJSGI-DJGI } \\
\text { difference } \\
\text { (per cent } \\
\text { points of the } \\
\text { total) }\end{array}$ & $\begin{array}{c}\text { DJGI } \\
\text { cumulative } \\
\text { performance } \\
\text { Q1:1995- } \\
\text { Q4: } 1999(\%)\end{array}$ & $\begin{array}{c}\text { DJSGI-DJGI cumulative } \\
\text { returns difference } \\
\text { (DJGI performances) } \\
\text { Q1:1995-Q4: 1999 } \\
(\%)\end{array}$ \\
\hline Americas (excl. USA) & 2.41 & 128 & 3.08 \\
\hline USA & -11.69 & 266 & -31.10 \\
\hline Europe (excl. S. Africa) & 13.79 & 233 & 32.13 \\
\hline Pacific & -4.70 & 41 & -1.93 \\
\hline World (excl. S. Africa) & - & $\mathbf{1 7 0}$ & $\left(^{*}\right) \mathbf{2 . 1 8}$ \\
\hline$\left(^{*}\right.$ The reported DJSGI-DJGI performance difference is 50.05.
\end{tabular}
Information retrieved from: Table 5 and Dow Jones (2000a; 2000b; 1999b) available at indexes.dowjones.com/djgi/ as well as the five-year performance data retrieved from DJGI Data Server.

Table 6. Regional distribution of corporations in the DJSGI through to March 31, 2000 (Dow Jones, 2000d).

\begin{tabular}{|l|c|c|}
\hline Regional distribution & $\begin{array}{c}\text { Number } \\
\text { of corp. }\end{array}$ & $\begin{array}{c}\text { Market } \\
\text { capitalisation } \\
\text { (million USD) }\end{array}$ \\
\hline Americas (excl. USA) & 18 & 300,661 \\
\hline USA & 46 & $2,006,654$ \\
\hline Europe (excl. S. Africa) & 112 & $2,296,797$ \\
\hline Pacific & 46 & 691,894 \\
\hline World (excl. S. Africa) & $\mathbf{2 2 2}$ & $\mathbf{5 , 2 9 6 , 0 0 6}$ \\
\hline
\end{tabular}

Multiplying DJSGI-DJGI regional distribution differences by DJGI regional performances has shown that a small portion of the higher DJSGI performance may originate from the asymmetric regional market distribution. The largest differences in the regional distributions of the DJSGI (predominantly European) and the DJGI (predominantly US) neutralise the resulting performance differences. 


\section{Average market capitalisation comparisons}

The DJSGI is made up of some 226 of the DJGl's total 2899 companies and represents about $20 \%$ of the DJGI's capitalisation value. By dividing the total capitalisation values of the respective indexes by the numbers of incorporated companies contained in each, the average capitalisation value of corporations in each index can be estimated. Table 7 shows an asymmetric distribution of the average market capitalisation value of companies in each of the two indexes. The average market capitalisation of companies in the DJSGI is twoand-a-half times larger than the corresponding value in the DJGI (Dow Jones, 1999c; 2000c; 2000d) (see Table 7).

Table 7. Average market capitalisation value of corporations in the

\section{DJGI and the DJSGI.}

\begin{tabular}{|l|c|r|}
\hline (Averages) & $\begin{array}{c}\text { DJGI } \\
(80 \% \text { coverage of } \\
\text { world exchange } \\
\text { capital) }\end{array}$ & $\begin{array}{c}\text { DJSGI } \\
(19.49 \% \text { of } \\
\text { DJGI capital) }\end{array}$ \\
\hline Market capitalisation (million USD) & $25,120,000$ & $4,896,000$ \\
\hline Number of companies & 2899 & 226 \\
\hline Market capitalisation (million USD) / company & 8,665 & 21,664 \\
\hline
\end{tabular}

Large capitalisation companies in the DJGI have an average of 5.2 times the average market capitalisation of the same index. Table 8 shows that large companies have a 14 per cent unit higher growth than the DJGI as a whole. Another indication that large market capitalisation results in higher stock market performance can be shown by introducing the Dow Jones Global Titans Index (DJGT), which represents 50 of the world's 100 largest corporations. The DJGT outperformed the DJGI from the first quarter of 1993 to the fourth quarter of 1999 by approximately 45 per cent points (DJGT, 2000:www). This performance is quite similar to the surplus of larger corporations in the DJSGI compared to the DJGI. Adding the capitalisation of all the DJGT companies together produces a total market capitalisation of USD 6,203,232 million. The average corporate capitalisation in the DJGT comes to USD 124,065 million, 
which is about six times larger than the corresponding figure in the DJSGI and 14.3 times larger than the corresponding figure in the DJGI (Dow Jones Indexes, 2000www).

Table 8. Size distribution comparisons of Dow Jones Global Index performances.

\begin{tabular}{|l|c|c|c|}
\hline $\begin{array}{l}\text { Return growth } \\
(95 \% \text { coverage of world } \\
\left.\text { exchange capital }{ }^{*}\right)\end{array}$ & $\begin{array}{c}\text { MKTCAP I } \\
\text { Company } \\
\text { (million USD) }\end{array}$ & MKTCAP / All & $\begin{array}{c}\text { MKTCAP CHANGE } \\
\text { Q1:1995-Q4:1999 } \\
(\%)\end{array}$ \\
\hline Large capitalisation & 32,343 & 5.2 & 171.70 \\
\hline Mid capitalisation & 3,117 & 0.5 & 137.58 \\
\hline Small capitalisation & 609 & 0.1 & 135.86 \\
\hline All & 6,212 & 1 & $\mathbf{1 4 . 2 0}$ \\
\hline Difference (All-LC) & & & 157.50 \\
\hline
\end{tabular}

Information (size distribution and five-year performance) is retrieved from DJGI Data Server available at indexes.dowjones.com/ .

*(A somewhat different regional distribution than the ' $80 \%$ coverage of world exchange capital.')

The Dow Jones STOXX Index and the Carnegie indexes show that large and extremely large companies experienced higher market capitalisation growth rates than middle and smaller-sized companies during the 1990s. There appears to be a correlation between companies showing larger market capitalisation and their higher performance in the stock markets. As the average market capitalisation value of companies in the DJSGI is found to be two-and-ahalf times larger than the company average in the DJGI, some of the higher performance in the DJSGI may result from larger market capitalisation. About $14 \%$ of the DJSGI's higher growth than the DJGI is due to company size. 


\section{Discussion and conclusions}

Results of "backcasting" from 1998 to 1993 reveal that the DJSGI outperforms the DJGI (Dow Jones, 1999a). Historical data from the DJSGI in 1999 and graphs of the performance of the DJSGI in 2000 indicate no major change in this trend (Dow Jones, 2001www). A regional exception to this is Europe, where the DJSGI has slightly under-performed the DJGI. According to the Dow Jones Sustainability Group Indexes $\mathrm{GmbH}$, the reason for the performance difference in favour of the DJSGI is that those corporations included in the DJGI have been more profitable than their DJSGI counterparts at dealing with economic, social, and environmental opportunities and risks (Dow Jons, 1999a; 1999b; 2000c; 2000d). This is certainly hoped to be the case.

However, as pointed out in this article, there may be other underlying factors positively influencing the DJSGI's sustainability performance, for example: (a) the DJSGI focuses to a higher degree on the technology community than does the more generalised DJGl; and (b) the market capitalisation value of corporations in the DJSGI is two-and-a-half times larger than the corresponding average for the DJGI. High market capitalisation value and technology are seen here as contributing to the better performance of the DJSGI in 1993 and 1999 (see Figure 1). The superior performance of the DJSGI might not therefore be exclusively due to successful management of economical, social, and environmental opportunities and risks, but to other factors as well. 
Figure 1. Sector, regional and size distributions of DJSGI - DJGI related to DJGI performance, compared with reported DJSGI-DJGI performance differences,Q1:1995 - Q4:1999 (The three distribution performance differences can not be aggregated).

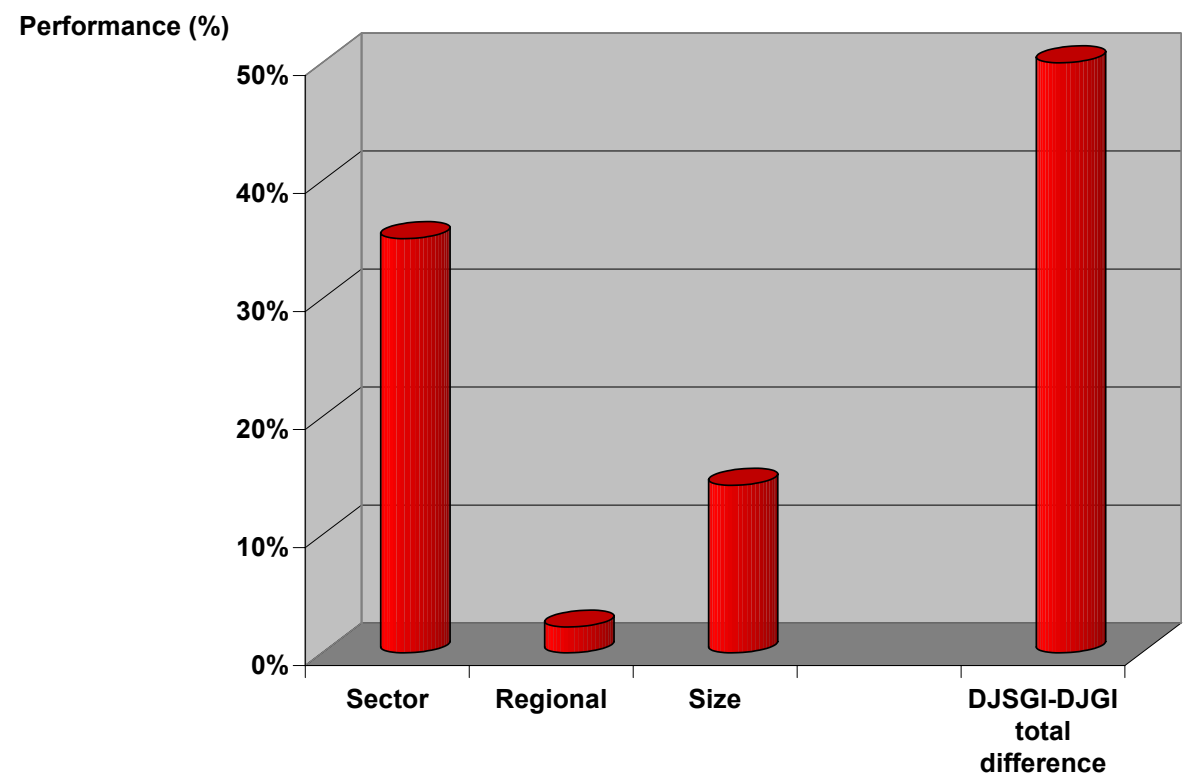

This study serves merely as a starting point for further research. It raises questions such as whether large corporate market capitalisation results from sustainability-driven corporations, or the converse. Partial indications are revealed in studies on municipal regions, where larger municipalities appear to have greater unutilised resources tucked away enabling them to become early movers in sustainability (Burström, 2000). Turning to indications in the electronics industry, smaller companies and smaller units within large corporations appear to have fewer resources available to commit to environmental analysis (Holgaard and Remmen, 2000; Cerin and Laestadius, 2000).

There are two interesting regional differences in US and European performances. First of all in the USA, the DJSGI performed 61 per cent points 
higher than the DJGI, but 20 per cent points lower in Europe (compare this with Table 2). Calculations in this study show that corporations in DJSGI Europe achieve half the average company capitalisation of corporations in the DJSGI USA. The second regional difference alluded to above, is that DJSGI Europe has proportionately fewer companies in the technology sector than the DJSGI USA (Carle, 2000). The two regional differences in DJSGI performance between USA and Europe discussed here may explain why the DJSGI outperforms the DJGI in USA and why the converse occurs in Europe.

An area of concern relating to the methodology of "backcasting" the performance of clusters of companies in the DJSGI ought to be raised here. The method carries with it an inherent risk for making erroneous assumptions that may result in incorrect index growth values. Jagrén has analysed the growth of both large and small Swedish companies over time (Jagrén, 1988; Eliasson, 1985). Jagrén found that the number of companies in the beginning of these studies had dropped considerably in comparisons undertaken 30 or more years later. Growing companies not only expand organically but also through acquisitions, and most of the companies in these studies had either gone into bankruptcy or been acquired. "Backcasts", such as those that the DJSGI study is based on, have to take into account the fact that today's companies are a selection of yesterday's winners. In order to increase the transparency of the DJSGI even further, it would be interesting to study how "backcasting" the index influenced the performance, especially the market capitalisation growth.

Another concern here is the fact that the questionnaire for establishing the DJSGI performance figures is based on company-intrinsic processes at the cost of neglecting products and services. This raises several questions. Could individual companies in sustainability-problematic industries be included in benchmarking tools such as the DJSGI? Would it be analytically possible to enclose a life-cycle perspective in such an index? What would actually be measured? 
No quantitative data on the generation of emissions or consumption of resources by companies, or their products or services, appears to have been used in the sustainability assessment criteria for the DJSGI. Managerial measurements are used extensively (accounted for by a number of management tools). We may not actually be comparing valid equivalents here. In addition, we do not really know what comes first - are sustainability-driven companies indeed becoming larger, or are larger companies adopting management tools for sustainability? We see the mere existence of the DJSGI, the use of DJSGI by investment managers, and the many references by managers to the index as a sign that sustainability efforts indeed have been hijacked (Welford, 1997; Rikhardsson and Welford, 1997).

Despite the concerns raised, and its bias towards both the technology sector and larger market capitalisation, the DJSGI provides analysts and others with an important tool for illuminating worldwide sustainability-driven processes. If the DJSGI is to remain a useful tool in the long run, it has to itself become more transparent in the process of bringing transparency to the sustainability of companies. Further research ought to examine the actual sustainability criteria used in the selection of DJSGI companies. 


\section{References}

Ball, A, Owen, D, Gray, R. 2000. External transparency or internal capture? The role of third-party statements in adding value to corporate environmental reports. Business Strategy and the Environment 9(1): 1-23.

Baylis, R, Connell, L, Flynn, A. 1998. Sector variation and ecological modernization. Towards an analysis at the level of the firm. Business Strategy and the Environment 7(3): 150-61.

Bowen, F. 2000. Environmental visibility. A trigger of green organizational response? Business Strategy and the Environment 9(2): 92-107.

Burström, F. 2000. Environment and Municipalities: Towards a theory on municipal environmental management. KTH/Högskoletryckeriet, Sweden, Stockholm.

Carle, G. 2000. Personal communication with a sustainability analyst from the SAM Sustainability Group at the Electronics Goes Green 2000+: A Challenge for the Next Millennium Conference, September 11-13, Berlin, Germany.

Cerin, P, Laestadius, S. 2000. The efficiency of becoming eco-efficient. The 2000 Eco-Management and Auditing Conference Proceedings, Manchester, UK: 44-53.

Dagens Industri/Fondstar. 2000www. As retrieved in June: http://di.fondstar.se/

Diamantis, D. 1999. The importance of environmental auditing and environmental indicators in islands. Eco-Management and Auditing 6(1): 1825. 
Dobers, P. 1999. Organizing environmental control in temporary local organizations. Business Strategy and the Environment 8(3): 163-76.

Dobers, P, Wolff, R. 2000. Competing with soft issues. From managing the environment to sustainable business strategies. Business Strategy and the Environment 9(3): 143-50.

Dow Jones 1999a. Dow Jones Indexes \& SAM Sustainability Group Launch Sustainability Indexes, Switzerland, Zurich.

Dow Jones 1999b. Dow Jones Global Indexes Quarterly Review. No. JulySeptember.

Dow Jones 1999c. Dow Jones Sustainability Group Index: Performance and Attributes. No. December.

Dow Jones 2000a. Dow Jones Global Indexes Quarterly Review. No. JanuaryMarch.

Dow Jones 2000b. Dow Jones Global Indexes Quarterly Review. No. AprilJune.

Dow Jones 2000c. Dow Jones Sustainability Group Index: Performance and Attributes. No. January.

Dow Jones 2000d. Dow Jones Sustainability Group Index: Performance and Attributes. No. March.

Dow Jones Indexes. 2000www. As retrieved in the period of May to September: http://indexes.dowjones.com/ 1) Dow Jones Global Indexes, 2) Dow Jones Global Titans Index, 3) Dow Jones STOXX index, 4) Dow Jones Sustainability Group Index. 
Dow Jones 2001www. Dow Jones Sustainability Group Index: Performance and Attributes (as retrived on February 22: http://www.sustainabilityindex.com/performance.cfm.

Eliasson, G. 1985. De svenska storföretagen. IUI: Stockholm.

Herremans, I, Welsh, C, Kane, D, Bott, R. 1999. How an environmental report can help a company 'learn' about its own environmental performance. EcoManagement and Auditing 6(4): 158-69.

Holgaard, J, Remmen, A. 2000. Cleaner technology in the electronic industry. The 2000 Eco-Management and Auditing Conference Proceedings, Manchester, UK: 122-130.

Jagrén, L. 1988. Företagens tillväxt i historiska perspektiv. In: Expansion, avveckling och företagsvärdering i svensk industri. En studie av ägarformens och finansmarknadernas betydelse för strukturomvandlingen. Örtengren (ed). Almqvist \& Wiksell International: Stockholm.

Kolk, A. 1999. Evaluating corporate environmental reporting. Business Strategy and the Environment 8(4): 225-37.

Kolk, A, Walhain, S, van de Wateringen, S. 2001. Environmental reporting by the Fortune Global 250. Exploring the influence of nationality and sector. Business Strategy and the Environment 10(1): 15-28.

Ljungdahl, F. 1999. Utvecklingen av miljöredovisningen i svenska börsbolag praxis, begrepp, orsaker. Lund University Press, Sweden.

Niskanen, J, Nieminen, T. 2001. The objectivity of corporate environmental reporting. A study of Finnish listed firms' environmental disclosures.

Business Strategy and the Environment 10(1): 29-37. 
Ransom, P, Lober, D. 1999. Why do firms set environmental performance goals? Some evidence from organizational theory. Business Strategy and the Environment 8(1): 1-13.

Rikhardsson P, Welford, R. 1997. Clouding the crises: The construction of corporate environmental management. Welford, R. (ed). Hijacking environmentalism: Corporate responses to sustainable development. Earthscan Publications Ltd. UK, London: 40-62.

Robinson, D, Clegg, A. 1998. Environmental leadership and competitive advantage through environmental management system standards. EcoManagement and Auditing 5(1): 6-14.

Stead, E, McKinney, M M, Stead, J G. 1998. Institutionalizing environmental performance in US industry. Is it happening and what if it does not? Business Strategy and the Environment 7(5): 261-70.

Welford, R. 1997. Hijacking environmentalism: Corporate responses to sustainable development. Earthscan Publications Ltd. UK, London.

WCED (World Commission on Environment and Development). 1987. Our common future. Oxford University Press: Oxford.

Wheeler, D, Elkington, J. 2001. The end of the corporate environmental report? Or the advent of cybernetic sustainability reporting and communication. Business Strategy and the Environment 10(1): 1-14. 


\section{Acknowledgements}

The authors would like to thank Peter Collopy, Staffan Laestadius and Hans Lööf for their constructive comments, and suggestions for improving the paper. Peter Dobers would like to acknowledge the generous financial support received from the Jan Wallanders and Tom Hedelius Foundation and the Malmsten Foundation. Pontus Cerin would like to acknowledge the generous financial support received from: (1) King Carl XVI Gustav of Sweden through his fund dedicated to science, technology and the environment, (2) the Swedish Council for Planning and Coordination of Research, and (3) the Department of Industrial Economics and Management at the Royal Institute of Technology in Stockholm. 